\title{
Bankruptcy Risk Prediction in Ensuring the Sustainable Operation of Agriculture Companies
}

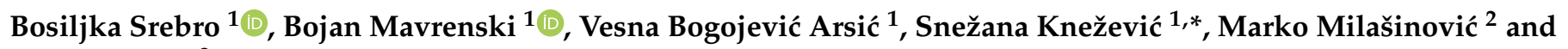 \\ Jovan Travica $^{3}$ \\ 1 Faculty of Organizational Sciences, University of Belgrade, 11000 Belgrade, Serbia; b.spasic@yahoo.com (B.S.); \\ mavrenskibojan@gmail.com (B.M.); bogojevic-arsic.vesna@fon.bg.ac.rs (V.B.A.) \\ 2 Faculty of Hotel Management and Tourism in Vrnjačka Banja, University of Kragujevac, \\ 36210 Vrnjačka Banja, Serbia; marko.milasinovic@kg.ac.rs \\ 3 Faculty of Business, Singidunum University, 11000 Belgrade, Serbia; jtravica@singidunum.ac.rs \\ * Correspondence: snezana.knezevic@fon.bg.ac.rs
}

Citation: Srebro, B.; Mavrenski, B.; Bogojević Arsić, V.; Knežević, S.;

Milašinović, M.; Travica, J.

Bankruptcy Risk Prediction in

Ensuring the Sustainable Operation

of Agriculture Companies.

Sustainability 2021, 13, 7712. https://

doi.org/10.3390/su13147712

Academic Editor: Olaf Weber

Received: 11 June 2021

Accepted: 6 July 2021

Published: 10 July 2021

Publisher's Note: MDPI stays neutral with regard to jurisdictional claims in published maps and institutional affiliations.

Copyright: (C) 2021 by the authors. Licensee MDPI, Basel, Switzerland. This article is an open access article distributed under the terms and conditions of the Creative Commons Attribution (CC BY) license (https:/ / creativecommons.org/licenses/by/ $4.0 /)$.

\begin{abstract}
In recent decades, predicting company bankruptcies and financial troubles has become a major concern for various stakeholders. Furthermore, because financially sustainable businesses are affected by numerous highly complex factors, both internal and external, the situation is even more complex. This paper applies Altman's Z-score models; more precisely, the paper applies the initial Z-score model (a model for manufacturing companies), the $Z^{\prime}$-score model (for companies operating in emerging markets), and the Z-score bankruptcy probability calculation. Therefore, this paper offers the results of the application of different Z-score models and the calculation of bankruptcy probability on a sample of agricultural companies listed on the Belgrade Stock Exchange in the period 2015-2019. In addition, different Z-score models are used for the same sample so that the difference between their results and application can be determined. In addition, the validity of the data published in the financial statements of the respective companies was confirmed using the Beneish M-score model with five and eight variables. The results obtained by applying Altman's Z-score model (initial and adapted to emerging markets) indicate that a certain number of companies had impaired financial stability during the observed period, i.e., that they were in danger of bankruptcy. In addition, based on the results obtained using the Beneish M-score model, it was identified that a number of companies showed signals that indicate possible fraudulent financial reporting. Further, it was found that less than half of the observed companies reported on environmental protection in their annual reports, and they did so by providing a modest amount of information. The originality and value of the paper lies in suggesting that policymakers in the Serbian emerging markets should pay more attention to the operations of companies from the observed sector, as well as to their financial and non-financial reporting. Future research should focus on comparisons with agricultural companies from the same sector whose securities are listed on stock exchanges in the region.
\end{abstract}

Keywords: bankruptcy; risk prediction; agricultural companies; Altman's Z-score model; Beneish M-score model

\section{Introduction}

Despite the growing focus on the information and communication technology sector, the agricultural sector is still an important part of the economy of the Republic of Serbia [1]. In the Republic of Serbia, agriculture has economic, political, and social significance [2,3], and its share in gross domestic product (GDP) during 2019 was 6\% [4]. In addition, agriculture employment as a share of the total number of employees in the Republic of Serbia is still significant, and the combination of the agriculture and food industries constitutes a significant share of the Republic of Serbia's export structure [5]. As a result of these factors, agriculture, in conjunction with the food industry (as its accompanying activity), represents a strategic economic branch in the Republic of Serbia [6]. 
Despite the favorable natural conditions (soil and climate) for the production of various agricultural products, and access to experienced producers, top experts, and scientists [7], companies in the agricultural sector of the Republic of Serbia face substantial challenges that prevent them from realizing their full potential [8]. Agricultural companies in the Republic of Serbia face low sales prices and rising production costs [9]. The process of privatization has led to the fragmentation of large agricultural complexes, leaving a number of workers jobless. In addition, Stanojević et al. [10] emphasize the need to improve the technological equipment of agricultural enterprises, increase the level of technological efficiency, and retrain employees to increase production. One of the challenges faced by agricultural enterprises is the insufficient availability of financial resources [11], in addition to the inadequacy of the financial system as regards the needs of these enterprises [12].

At present, modern agriculture has become not only a trend in global agriculture, but also a focus of development and construction in all countries. This is important to ensuring an efficient agricultural supply and food security, among other goals [13]. Recently, a greater focus has been placed on sustainable intensification in agribusiness development [14].

At present, a significant discussion is taking place about how to promote sustainable development, and what is meant by balancing economic, environmental, and social aspects. Players from different industrial sectors regard sustainable development differently, and for a clear understanding of sustainability practices in different industrial sectors, it is necessary to agree to a definition of sustainability [15]. The economic system itself is a managed sub-ecosystem of the sustaining and continuing global ecosystem [16].

Understanding agricultural production implies the necessity of considering various factors, such as inputs, products, processes, and relationships, across value chains and within their cultural, economic, environmental, political, and social contexts [17]. Dillard et al. state that research on the social aspects of sustainability is given much less importance compared to long-term economic and environmental sustainability [18]. The issues related to soil quality losses are intensified by the transition to modern agriculture and all of the changes associated with it [19]. Today, agro-firms face extremely fierce competition from global suppliers in both the domestic and export markets, and this grounds the need for significant transformation in order for them to be competitive [20]. In this context, it is emphasized that innovations and technological transfers in the promotion of agricultural productivity are of special importance [21].

Three research questions are defined in this article.

- V1. How many companies within the sector have come into a position of possible bankruptcy?

- V2. How many companies that have been tested for possible bankruptcy are linked to fraudulent financial reporting?

- V3. What is the number of analyzed companies that disclosed environmental data in their annual financial statements?

Sustainability should be treated as a dynamic and evolving concept, and as a verb rather than a noun [22]. In the current business scenario, the most advanced manufacturing organizations consider sustainability from the perspective of competitiveness, on the one hand, and in the context of the business imperative to satisfy various stakeholders, on the other [23]. Sustainability is of primary importance to organizations [24]. Unlike companies that have adopted sustainability initiatives based on compliance with current legislation, a number of companies have voluntarily introduced practices to increase their social, environmental, and economic performance beyond what is legally required [25]. The results of the study by Ratri et al. [26] have shown that companies with CEOs who frequently attend board meetings engage in much more CSR disclosure. The results of the research of Ordóñez et al. [27] indicate that the most indebted and largest companies disclose less information about the environment, in contrast to companies that are classified as having high solvency. 
The impact of sustainability practices on driving business growth, particularly those related to the environment and society, is evident from the annual reports on the sustainability of large corporations. In addition, a large amount of research has been conducted on the sustainability performance, and financial performance, of large corporations. This is in contrast to small and medium-sized enterprises, particularly those in emerging economies, whose responsibilities to the environment and society have been grossly neglected [28]. Global and national markets have been characterized by instability in recent years. In response to changes in the operational environment, organizations have adopted a variety of practices to ensure sustainable development via threat forecasting and risk management $[29,30]$. A prerequisite for the establishment of sustainable agricultural practices is the provision of environmentally friendly technologies that can be applied in agriculture [14].

Globalization and the rise of the knowledge economy have led to the redefinition of the role of universities in society [31]. Given their complexity, sustainability issues cannot easily be transferred to universities, nor can this be accomplished quickly [32]. The more active involvement of management accountants depends, among other things, on their ability to broaden their competencies to include other domains of expertise, and on the role of accounting education in improving sustainability knowledge [33]. Education is an important pillar in ensuring sustainable development, because it teaches people what it means to be environmentally responsible [34]. Scientists within the natural and social sciences have, since the 1960s, highlighted a number of important issues of sustainable development and, since then, research into the problem of sustainable development has expanded in many organizations [35]. An example of well-integrated educational practice is that of the UK, where sustainability courses at masters levels integrate modules on social, economic, and environmental issues of sustainable development [36].

The concept of financial sustainability refers to liquidity, long-term returns, growth potential, and the ability to withstand financial distress. Ignoring the signs of financial distress can lead to a situation in which bankruptcy is the only option. A generally accepted definition of bankruptcy is that it presents a condition in which a company cannot pay out its creditors, suppliers, shareholders, etc. Bankruptcy has a vast impact on a company's existence and incurs enormous expenses for the company itself, the company's associates (other companies and organizations), society, and the economy of the entire country [37]. Furthermore, there is a clear necessity for bankruptcy prediction tools and methods in order to avoid expenses for many stakeholders. Bankruptcy prediction is of great importance for company owners or shareholders (depending on the type of entity), managers, employees, creditors, suppliers, clients, communities, and entire countries [38], and if the prediction is sufficiently accurate and early, bankruptcy and all of its related expenses can be avoided.

The modern economy is in a state of constant expansion under the influence of the globalization phenomenon, the advancement of technology and communication channels, and frequent and unpredictable changes. Many companies globally are finding it difficult to keep up with the pace of these events, and often suffer failure and enter bankruptcy. The corporate life cycle generally encompasses periods of financial difficulties which, in the worst-case scenario, can lead to bankruptcy or reorganization. Furthermore, bankruptcy presents chronic rather than temporary conditions [39]. Schumpeter [40] named the process of the constant creation and failure of companies "creative destruction", implying that it is the "essential fact of capitalism".

In the decision-making process, management is oriented toward the use of integral information, within which the accounting system is the most important factor. An accounting information system is a powerful tool in the hands of managers who strive to retain a competitive advantage in the midst of rapid technological progress, and when facing the growing challenges posed by customers and business owners [41].

The paper is organized as follows. After an introductory consideration, the Altman Z-score and Beneish M-score models are presented. The third section presents the research methodology. The results of the research are presented in the fourth section. In the 
last section, the concluding considerations and limitations of the research are presented, from which the directions of future research arise.

\section{Predicting Bankruptcy Using Altman's Z-Score Model and Determining the Possibility of Fraudulent Financial Reporting Using the Beneish M-Score Model}

Financial statements disclose the operations and assets for which managers are responsible in terms of whether they use them effectively in business. In addition, it is important to note that companies' financial statements mostly focus on hard resources, such as facilities, real estate, and inventories, but do not provide information on soft resources related to intangible assets (human resources-knowledge, skills).

The management of the business entity is the basic bearer of the legal responsibility for the true and objective presentation of financial position, business results, and changes to the company's financial position. The company's management has the primary responsibility of preparing and presenting the company's financial statements. Financial information disclosed by economic entities is subject to control by financial auditors who should assess the compliance of financial statements with accounting standards in force in a country [42]. The auditing profession guarantees the reliability of financial statements, and in this context, high value is placed on the application of bankruptcy prediction models. These models may signal the existence of signs of financial difficulties, which should be disclosed in audit reports because this information is of special importance when making various types of economic decisions for different interest groups. Numerous examples of financial fraud from the past and at the beginning of this century have disrupted the trust of a large number of users in financial information published in financial statements, which has further affected the financial reporting system, and the accounting and auditing profession is often accused of being responsible for losing confidence in the credibility of the financial information on which numerous economic decisions are based [43].

The quality of management is a very important factor in the efficiency and profitability of any company, regardless of the type of activity and its size [44]. The most frequent reason for corporate distress and eventual bankruptcy is management incompetence. According to Dun and Bradstreet, more than $70 \%$ of bankruptcies have occurred because of incompetent management [45]. In addition, the main cause of bankruptcy is the loss of liquid assets, although there are many other causes. The most common causes of bankruptcy are as follows [46]:

1. Poor operating performance and high financial leverage-poor acquisitions, vast competition, input cost fluctuations, etc.;

2. Lack of technological innovation-the failure of many companies has been due to a lack of innovation;

3. Liquidity and funding shock-Potential funding risk is known as rollover risk. In times of a small credit supply, some companies are not able to roll over their maturing debt;

4. Relatively high new business formation rates in certain periods-Business formation is tightly linked to positive expectations in the future. However, the rate of distress is substantially larger for new companies compared to older ones;

5. The deregulation of key industries-deregulation means the removal of governmental protection for certain industries.

Financial ratios provide information concerning assets, rentability, liquidity, debt, and all other aspects that influence the financial performance and credit rating of a company. Hutahayan [47] emphasizes that organizational performance is multidimensional because it includes financial and non-financial performance, and that financial performance is the most important aspect for shareholders. In particular, the author emphasizes that performance shows whether a company's strategy is contributing to bottom-line improvements. 
Financial analysis starts from a company's financial reports and strives to explore the relations between certain financial report positions in order to evaluate their size and significance. Thus, financial analysis is reduced to ratio analysis. Ratios have a certain value only if they are precisely and correctly interpreted; in other cases, ratios only present a relation between financial report positions. Thus, the goal is not the ratio itself, because it has to be usable and to give certain information that can lead to relevant conclusions. Many bankruptcy prediction models for companies are built using accounting-based financial ratios. Measuring company performance plays a particularly important role in improving the quality of business decisions and increasing business activity. Effective performance measurement is key to ensuring that a profit-oriented organization's strategy is successfully implemented.

The analysis of financial ratios is used in ongoing businesses on a regular basis, but not after a company has entered bankruptcy. In a broader sense, financial success can refer to the degree to which financial goals are met and, in this sense, it is emphasized that this has a special place in the process of financial risk management in profit-oriented companies. Measuring a company's financial health is an important activity throughout the accounting period, rather than only at the end of the period. A particularly important task of the management of each company is to determine key factors according to their impact on the company's profitability, which in a practical environment is often a very complex task. The prediction of bankruptcy years prior to its occurrence is of immeasurable importance [48].

Statistically verified predictive models have long been used in business studies, and when valid, they predict events with a high level of accuracy, which is of particular importance for business analysts [49]. Regarding financial distress models, Calandro states that, on principle, strategists have not yet noticed their great potential as performance management tools [50]. Seppa states that the signaling power of insider debt should be built into bankruptcy prediction models [51].

The results of the study by Purves et al. showed that a well-functioning management team or board is part of the success factor that can protect companies from failure [52]. Salehi et al. state that, given the growing number of companies in financial distress, which would lead to an increasing number of companies in bankruptcy, the need to predict the financial future of companies is becoming increasingly important [53]. In this context, they further state that forecasting models of financial distress are of particular importance for the business decision-making of various stakeholders in organizations, including auditors, creditors, and shareholders. Marinšek's research showed that companies with excessive leverage have a significantly higher probability of bankruptcy, emphasizing the importance of the concept of optimal corporate capital structure [54]. Hu and Zheng consider several factors in financial distress research, such as solvency and liquidity capacity, development capability, risk level, the capacity to maintain profitability, operational capacity, and cash flow generation capacity [55].

For the purpose of predicting the occurrence of bankruptcy, a large number of models have been developed, and a number of these can be used as a supplement to the analysis of financial statements, with the aim of detecting fraud in financial statements, in addition to predicting the bankruptcy that may arise from financial fraud [56]. The most commonly used are the Altman Z-score model and the Beneish M-score model.

Studies prior to that of Altman's Z-score [57] predominantly used univariate models (the most well-known work on the subject is that of W. H. Beaver [58]), but Altman specifically chose multiple discriminant analysis (MDA) to avoid potentially misleading results and signals from individual ratios [59]. For example, poor profitability and/or solvency can potentially point to bankruptcy, but if the same company has above-average liquidity, the situation can be regarded as not concerning. In his work, Altman chose five variables/ratios, combined them, and created his first Z-score model. The initial Z-core model has the following form:

$$
Z=1.2 x_{1}+1.4 x_{2}+3.3 x_{3}+0.6 x_{4}+0.999 x_{5}
$$


where the presented ratios are as follows:

$x_{1}=$ Working Capital/Total Assets;

$x_{2}=$ Retained Earning/Total Assets;

$x_{3}=$ Earnings Before Interests and Taxes (EBIT)/Total Assets;

$x_{4}=$ Market Value of Equity /Book Value of Total Liabilities;

$x_{5}=$ Sales $/$ Total Assets.

The mechanism of MDA-classifying an observation into one of several a priori groupings-is similar to that of the Z-score, because it classifies companies from a chosen sample as bankrupt and non-bankrupt. Altman tested the initial Z-score on a sample of 66 manufacturing companies, of which 33 entered bankruptcy prior to his test and 33 were healthy companies. The test accurately classified $95 \%$ of companies in the sample as bankrupt and non-bankrupt one year before bankruptcy. Altman then continued to observe the results of misclassified companies to define the ranges of classifying areas, and categorized them as follows:

$\mathrm{Z}>2.99$ - The company is in the safe or green zone;

$1.81<\mathrm{Z}<2.99-$ The company is in the grey zone. There is the highest probability that the test will misclassify a company if it is situated in this area;

$\mathrm{Z}<1.81$ - The company is in a dangerous zone and there is a high risk of bankruptcy in the following period.

The Z-score model can not only be used to predict bankruptcy by a company itself in order to avoid and mitigate such situations, but it can also be used outside the organization by other stakeholders or potential stakeholders; for example, to provide essential information for possible mergers and acquisitions.

Because the initial Z-score model was developed for public companies, which can easily be seen in the variable $x_{4}$, Altman remodeled the Z-score so that it could be applied to companies operating in emerging markets, with the following form:

$$
E M Z^{\prime}=3.25+6.56 x_{1}+3.26 x_{2}+6.72 x_{3}+1.05 x_{4}
$$

In the same manner as the change in the discriminant coefficients and variable $x_{4}$, the ranges of the classifying areas were also changed:

EM $Z^{\prime}>5.85$ - The company is in the safe or green zone;

$3.75<$ EM Z $Z^{\prime}<5.85-$ The company is in the grey zone. There is the highest probability that the test will misclassify a company if it is situated in this area;

EM $Z^{\prime}<3.75-$ The company is in a dangerous zone, and there is a high risk of bankruptcy in the following period.

Z-score results can be converted into bankruptcy probability as a percentage. Showing data as percentages is the best manner to express the results, because this is the easiest means by which to understand and interpret the quantitative bankruptcy probability, even without prior knowledge of the Z-score models. Therefore, the bankruptcy probability formula has the following form [60]:

$$
P=1-\frac{e^{z}}{1+e^{z}}
$$

Bankruptcy prediction studies are also of immense importance for many companies and countries. To more precisely predict bankruptcy, numerous authors have adjusted the model to better suit the economy of their country. The necessity of adjustment arises because of differences between different economies, markets, and legislations in countries. The adaptation of the model requires the use of alternative ratios, although Altman's initial ratios were clearly the starting point for numerous authors in later studies. 
Aruldoss et al. state that the term bankruptcy means the financial failure of a business or an organization. Bankruptcy is the last phase of the economic life of a company that, in a certain manner, affects all entities in the economy, and predicting bankruptcy is important because it has a strong impact on the economy and causes various social problems [59]. If a company determines that its current debt payment obligations exceed its current cash flow, it may choose the option to consider bankruptcy claims to reduce its debt obligations. Financial distress in business is not a new phenomenon, but it has become an issue of special attention during the last decade since the global recession of 2018 [61]. Many unexpected situations, such as the COVID-19 pandemic, have led to the declaration of bankruptcy by many companies [62]. Cenciarelli et al. noted that intellectual capital performance measures are complementary measures to traditional performance measures, and can be used to improve bankruptcy prediction models [63]. If it is assumed that bankruptcy can be expected prematurely, investors of companies have the ability to secure their investment in terms of being able to take measures to reduce risk and job loss, and ultimately to avoid bankruptcy itself [64]. Linna notes that in the field of company law, little research has been devoted to sustainability in the context of insolvency proceedings compared to that of corporate social responsibility [65]. The question often arises in the academic literature about whether corporate social responsibility (CSR) improves the financial performance of a company [66]. As a result of research undertaken to identify effective methods for predicting financial crises, various patterns have been used to predict these crises [67].

Statistically verified predictive models have long been used in business studies [49]. Following Altman's basic study, linear discriminant analysis has been widely applied in a practical setting because it is simple in terms of its application [68]. Finally, Altman et al. investigated the prediction of bankruptcy in a sample of small and medium-sized enterprises, and examined the role of several qualitative and non-financial factors, including the age of the firm, the size of the firm, and the auditor's opinion [69]. They found that older and larger firms are less likely to default. Older companies have undergone a longer learning process, thus increasing the likelihood of their survival and growth [63]. The empirical results of the research of Gupta et al. suggest two important findings: first, the probability of survival (danger) increases (decreases) with the increasing size of the company, and companies in different categories of SME size have different determinants of bankruptcy; second, the factors initiating financial trouble are mostly unchanging [70].

Muminović et al. found that the original Altman model could not be successfully applied to Serbian companies [71]. The EMS model for the bankruptcy testing of public companies has been applied by various authors. Panrad applied this model to the agribusiness sector in the Stock Exchange of Thailand [72]. Rajin et al. showed that Kralicek's DF model more effectively indicates the financial state of the company than Altman's Z-score model, considering the characteristics of the market in which the model is formed [73]. Because the number of bankrupt companies in the Republic of Serbia has significantly increased, it is particularly important to emphasize the need to apply a model suitable for emerging economies [74].

The indicators that show the areas of manipulation are expressed by the following formula for the M-score [75]:

$M(5)$ score $=-6.056+0.823 D S R I+0.906 G M I+0.593 A Q I+0.717 S G I+0.107 D E P I$

$M(8)$ score $=-4.840+0.920 D S R I+0.528 G M I+0.404 A Q I+0.892 S G I+0.115 D E P I-0.172 S G A I-0.327 L V G I+4.697 T A T A$

The calculation of indicators is shown in Table 1. 
Table 1. Indicators of Beneish M-score model.

\begin{tabular}{|c|c|}
\hline Indicators & Calculation \\
\hline DSRI-Days' sales in receivable index & $\left(\right.$ Net Receivables $_{t} /$ Sales $\left._{t}\right) /$ Net Receivables $_{t-1} /$ Sales $\left._{t-1}\right)$ \\
\hline GMI-Gross margin index & {$\left[\left(\right.\right.$ Sales $_{t-1}-$ Cost of Goods Sold $\left._{t-1}\right) /$ Sales $\left._{t-1}\right] /\left[\left(\right.\right.$ Sales $_{t}-$ Cost of Goods Sold $\left._{t}\right) /$ Sales $\left._{t}\right]$} \\
\hline AQI-Asset quality index & $\begin{array}{l}\left.\left[1-\text { Current Assets }_{t}+\text { Plant, Property \& Equipment }_{t}+\text { Securities }_{t}\right) / \text { Total Assets }_{t}\right] /[1- \\
\left.\left(\left(\text { Current Assets }_{t-1}+\text { Plant, Property \& Equipment }_{t-1}+\text { Securities }_{t-1}\right) / \text { Total Assets }_{t-1}\right)\right]\end{array}$ \\
\hline SGI-Sales growth index & Sales $_{t} /$ Sales $_{t-1}$ \\
\hline DEPI-Depreciation index & $\begin{array}{l}\text { (Depreciation }_{t-1} /\left(\text { Plant, Property \& Equipment }_{t-1}+\right. \\
\left.\left.\text { Depreciation }_{t-1}\right)\right) /\left(\text { Depreciation }_{t} /\left(\text { Plant, Property \& Equipment }_{t}+\text { Depreciation }_{t}\right)\right)\end{array}$ \\
\hline $\begin{array}{l}\text { SGAI-Sales and general and administrative } \\
\text { expenses index }\end{array}$ & $\begin{array}{l}\left.\text { (Selling General \& Administrative Expense }{ }_{t} / \text { Sales }_{t}\right) /(\text { Selling General \& Administrative } \\
\text { Expense }_{t-1} / \text { Sales }_{t-1} \text { ) }\end{array}$ \\
\hline LVGI-Leverage index & $\begin{array}{l}{\left[\left(\text { Current Liabilities }_{t}+\text { Total Long Term Debt }_{t}\right) / \text { Total Assets }_{t}\right] /\left[\left(\text { Current Liabilities }_{t-1}+\right.\right.} \\
\left.\left.\text { Total Long Term Debt } t_{t-1}\right) / \text { Total Assetst }-1\right]\end{array}$ \\
\hline TATA-Total accruals to total assets & 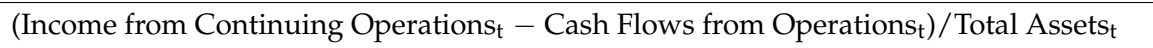 \\
\hline
\end{tabular}

If the value of the Beneish M-score model is greater than -2.22 , this indicates that fraud has occurred in the financial statements.

\section{Research Methodology}

The research was conducted on a sample of companies whose shares were listed on the Belgrade Stock Exchange within the sector A-Agriculture, forestry, and fishery on 1 January 2021. This sector is seventh in terms of market capitalization and fourth in terms of the value of turnover [76]. Of 31 companies whose shares were listed on the mentioned day, the research was conducted on a sample of 25 companies, and their business in the period from 2015 to 2019 was monitored. For the remaining 6 companies, financial reports were not publicly available on the official website of the Agency for Economic Registers of the Republic of Serbia [77]. Individual financial and audit reports of the companies were used as the source of data. In particular, data from the balance sheets, income statements, cash flow statements, annual business reports, and audit reports were used. The balance sheet, income statement, and cash flow statement were used to determine the values used in the Altman Z-score and Beneish M-score models [78]. Annual business reports were used as a source of non-financial information for the company's operations.

After the necessary data were gathered, the Z-scores were calculated in accordance Equations (1) and (2). Furthermore, after the Z-scores were calculated, bankruptcy probabilities were computed using Equation (3). Bankruptcy probabilities present clear and unambiguous quantitative expectations of bankruptcy in subsequent years, expressed as a percentage. By calculating the bankruptcy probability for the whole sample, in addition to the individual expectations of bankruptcy, a perspective for the whole sector can be obtained. Furthermore, the application of the Beneish M-score model, as shown in Equations (4) and (5), indicates the existence of fraudulent financial reporting in the observed companies.

\section{Results and Discussion}

The review of the annual business reports of the companies in the period from 2015 to 2019 showed that:

- $\quad$ Nineteen companies reported on the expected development of the company;

- Ten companies reported on environmental protection;

- $\quad$ Eighteen companies reported information related to research and development activities, whereas thirteen companies were found to have undertaken no such activities during the observed five-year period. 
A comparative review of the annual business reports found that, over time, companies that reported on expected development, environmental protection, and research and development did not increase the quality and quantity of disclosed information; that is, the companies disclosed the same data on the stated categories in the period from 2015 to 2019. In addition, it was determined that four companies did not disclose information on expected development, environmental protection, or research and development within the annual business reports.

The explanation for such a small amount of disclosed non-financial information (on the expected development of society, environmental protection, and research and development) within the annual business reports of the observed agricultural enterprises can be found in the fact that companies in the Republic of Serbia compile financial reports for tax authorities, and to comply with the legal requirements' framework, i.e., the reports have a formal significance, to be submitted to the Business Registers Agency [79]. Further, an obstacle to the collection of better and more extensive non-financial information is the lack of an adequate regulatory framework, and this improvement inevitably awaits solutions at the EU and global level [80]. An explanation for the scarce disclosed information can also be found in the fact that company managers, as those responsible for preparing financial statements, usually disclose less financial and non-financial information when the company is less successful in business [81,82]. The following results show that there is room to improve the business of the observed companies.

First, the result was calculated for the initial Z-score (Table 2). As can be seen from Table 2 and Figure 1, during the observed period, the largest share in the structure of the observed companies represents those operating in the red zone. It is a concern that, in the most recent observed year, more than half of the observed companies were classified into the mentioned zone. In summary, the results of the initial Z-score model do not show a promising future for sector A of the Belgrade Stock Exchange. Further, it is characteristic that during the observed five-year period, the minimum values of $Z$-score were achieved by one company. The maximum value of $Z$-score in the first three years was recorded by one company. One company recorded maximum Z-score values in 2018 and 2019.

Table 2. Results of the initial Z-score.

\begin{tabular}{cccccc}
\hline & $\mathbf{2 0 1 5}$ & $\mathbf{2 0 1 6}$ & $\mathbf{2 0 1 7}$ & $\mathbf{2 0 1 8}$ & $\mathbf{2 0 1 9}$ \\
\hline $\mathrm{Z}>2.99$ & 8 & 8 & 8 & 8 & 7 \\
\hline $1.81<\mathrm{Z}<2.99$ & 6 & 8 & 7 & 7 & 5 \\
\hline $\mathrm{Z}<1.81$ & 11 & 9 & 10 & 10 & 13 \\
\hline Min & -3.19 & -3.07 & -4.81 & -5.46 & -6.19 \\
\hline Max & 30.06 & 42.33 & 9.46 & 17.78 & 12.12 \\
\hline
\end{tabular}

Source: Author's analysis based on [76,77].

Next, we consider the calculation of the result of the $Z^{\prime}$-score, which is a model for companies who operate in emerging markets (Table 3). The results demonstrated in Table 2 and Figure 1 show that by using the $Z^{\prime}$-score for companies operating in emerging markets, the largest number of companies during the observed period were shown to operate within the green zone. On average, more than $65 \%$ of the observed companies had a Z-score model value higher than 5.85 during the observed period. The company that achieved the minimum values of the initial Z-score model in the period from 2015 to 2019 achieved the minimum values in the Z-score model for companies operating in emerging markets. The maximum values of the Z-score model for companies in the markets in the first two observed years were achieved by one company. 
Table 3. Results for the $Z^{\prime}$-score for companies operating in emerging markets.

\begin{tabular}{cccccc}
\hline & $\mathbf{2 0 1 5}$ & $\mathbf{2 0 1 6}$ & $\mathbf{2 0 1 7}$ & $\mathbf{2 0 1 8}$ & $\mathbf{2 0 1 9}$ \\
\hline $\mathrm{Z}>5.85$ & 17 & 18 & 16 & 17 & 16 \\
\hline $3.75<\mathrm{Z}<5.85$ & 4 & 4 & 5 & 4 & 4 \\
\hline $\mathrm{Z}<3.75$ & 4 & 3 & 4 & 4 & 5 \\
\hline Min & -15.59 & -15.88 & -22.45 & -25.99 & -29.72 \\
\hline Max & 56.28 & 77.80 & 20.28 & 35.16 & 25.29 \\
\hline
\end{tabular}

Source: Author's analysis based on [76,77].

The results of the Z-score model adjusted for companies operating in emerging markets show a better financial situation in the observed companies during the period 20152019, compared to the initial Z-score model (Figure 1).

Finally, after the calculation of the Z-score results, we consider bankruptcy probability. As mentioned previously, it is relatively simple to identify companies that are in a poor situation. As can be seen from Table 4, a number of companies face challenges to their survival in the coming period because they have a probability of bankruptcy greater than $50 \%$. Finally, auditors should look for potential signs of financial distress and, through the audit report, alert their users. However, by reviewing the audit reports of the observed companies, it was determined that the auditors usually do not indicate potential financial difficulties in the company's operations; it was determined that auditors include financial problems and business vulnerabilities within their audit report in fewer than $50 \%$ of companies that are in the red zone.

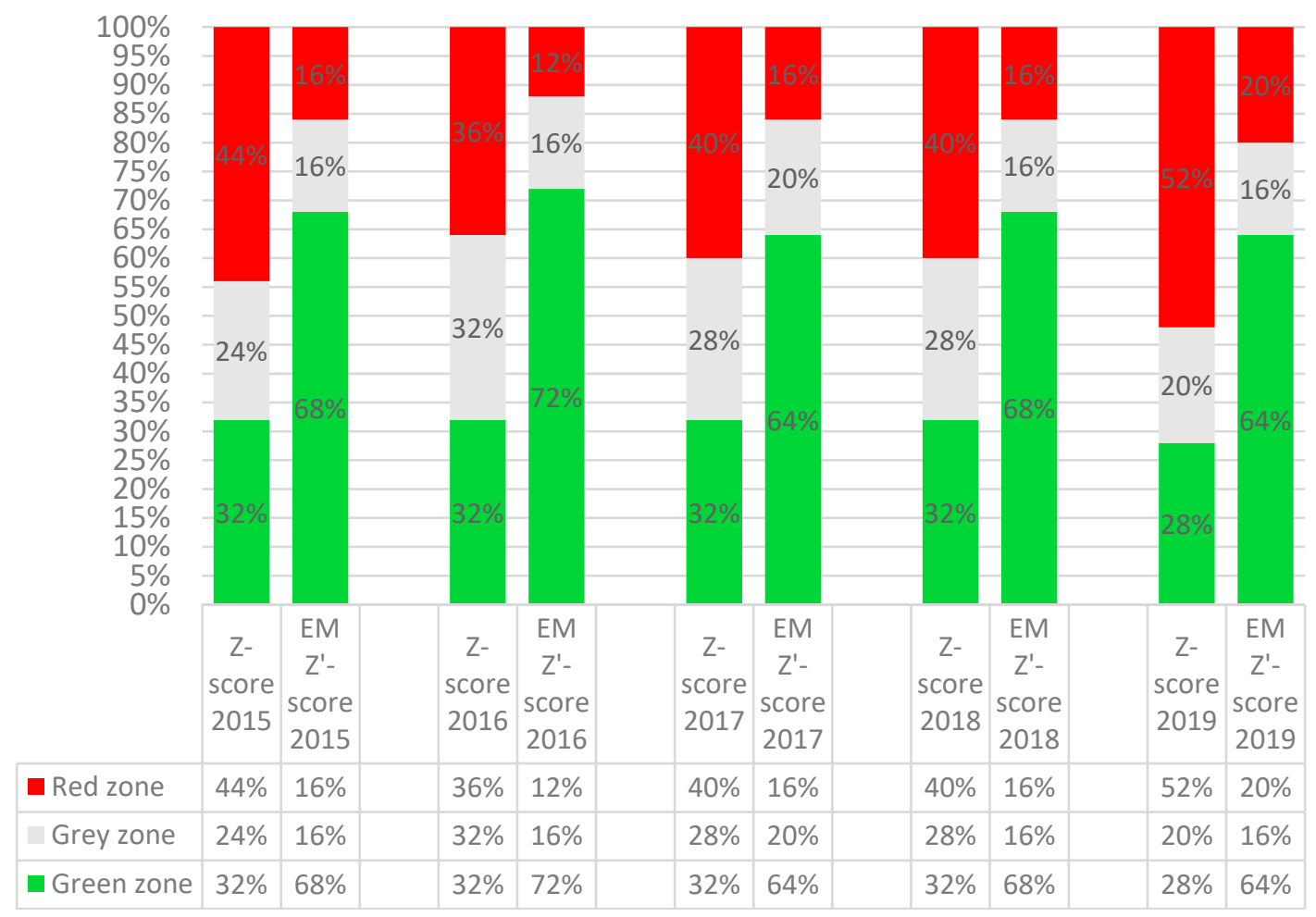

Figure 1. Classifying area percentages per year and according to different Z-scores. Source: Author's analysis based on $[76,77]$. 
Table 4. Probability of bankruptcy of Z-score and EM Z-score model.

\begin{tabular}{ccccccccccc}
\hline \multirow{2}{*}{$\begin{array}{c}\text { Bankruptcy } \\
\text { Probability }\end{array}$} & \multicolumn{4}{c}{ Z-Score Model } & \multicolumn{7}{c}{ EM Z-Score Model } \\
\cline { 2 - 12 } & $\mathbf{2 0 1 5}$ & $\mathbf{2 0 1 6}$ & $\mathbf{2 0 1 7}$ & $\mathbf{2 0 1 8}$ & $\mathbf{2 0 1 9}$ & $\mathbf{2 0 1 5}$ & $\mathbf{2 0 1 6}$ & $\mathbf{2 0 1 7}$ & $\mathbf{2 0 1 8}$ & $\mathbf{2 0 1 9}$ \\
\hline $0-25 \%$ & 18 & 17 & 19 & 19 & 20 & 19 & 18 & 20 & 20 & 20 \\
\hline $26-50 \%$ & 4 & 5 & 2 & 4 & 3 & 3 & 5 & 2 & 2 & 1 \\
\hline $51-75 \%$ & 1 & 1 & 2 & 1 & 0 & 1 & 0 & 1 & 1 & 2 \\
\hline $76-100 \%$ & 2 & 2 & 2 & 1 & 2 & 2 & 2 & 2 & 2 & 2 \\
\hline Source: Author's analysis based on [76,77].
\end{tabular}

The value of the Beneish M-score model with five variables in the period 2016-2019 is shown below (Figure 2). Due to the unavailability of data (publicly available) for 2014, it was not possible to determine the value of the model for 2015. As can be seen from Figure 2, the largest number of observed companies during the four-year period had a value for the M-score model below the threshold value $(-2.22)$, indicating that there are no signs that fraud was committed in the financial statements. However, in the two most recent observed years, the number of companies with an increased value for the M-score model indicates the possibility of fraud in the financial statements.

As in the case of the Beneish M-score model with five variables, the Beneish M-score model with eight variables showed that during the observed four-year period, there were no indications that a large number of agricultural enterprises committed fraud in their financial statements (Figure 2); that is, the largest number of observed agricultural enterprises had a value for the M-score model lower than -2.22 . However, as in the case of the five-variable model, there was an increase in the number of companies for which the value for the $\mathrm{M}$-score model indicated the possibility of fraud in financial statements. This is especially important when considering that financial statement fraud seems to be occurring at an increasing pace and with a growing magnitude [83].

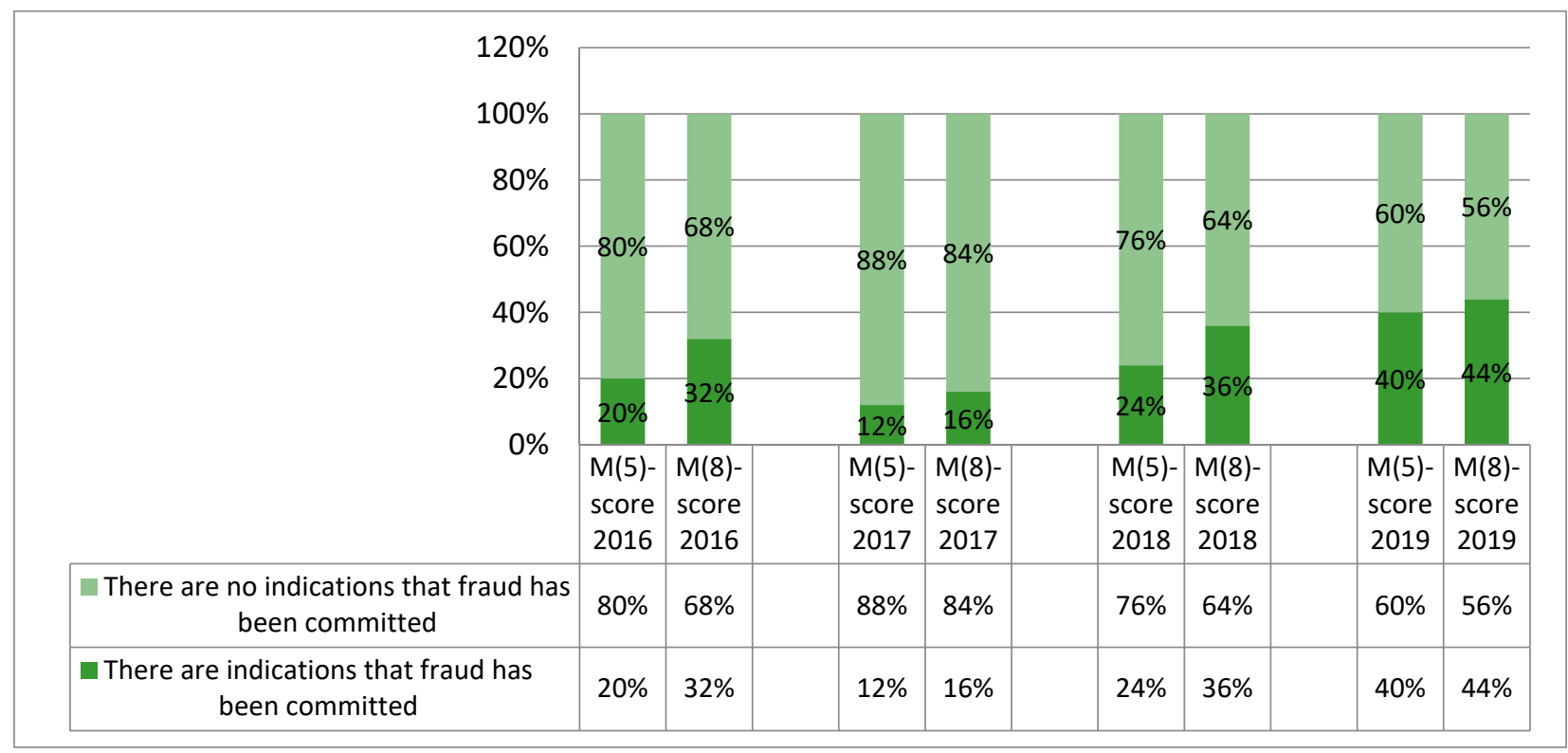

Figure 2. Classifying area percentages per year and according to different M-scores. Source: Author's analysis based on $[76,77]$.

The following is an overview of companies in which the application of the M-score model contained no indications that fraud was committed in the financial statements, whereby the assessment by "business zone" was performed using the initial Z-score and EM Z-score models. The results of the Z-score model adjusted for companies operating in 
emerging markets show a better financial situation in companies in which, in the period 2016-2019 and using the M-score model with five variables, there were no indications that fraud was committed in the financial statements, compared to the initial Z-score model (Figure 3).

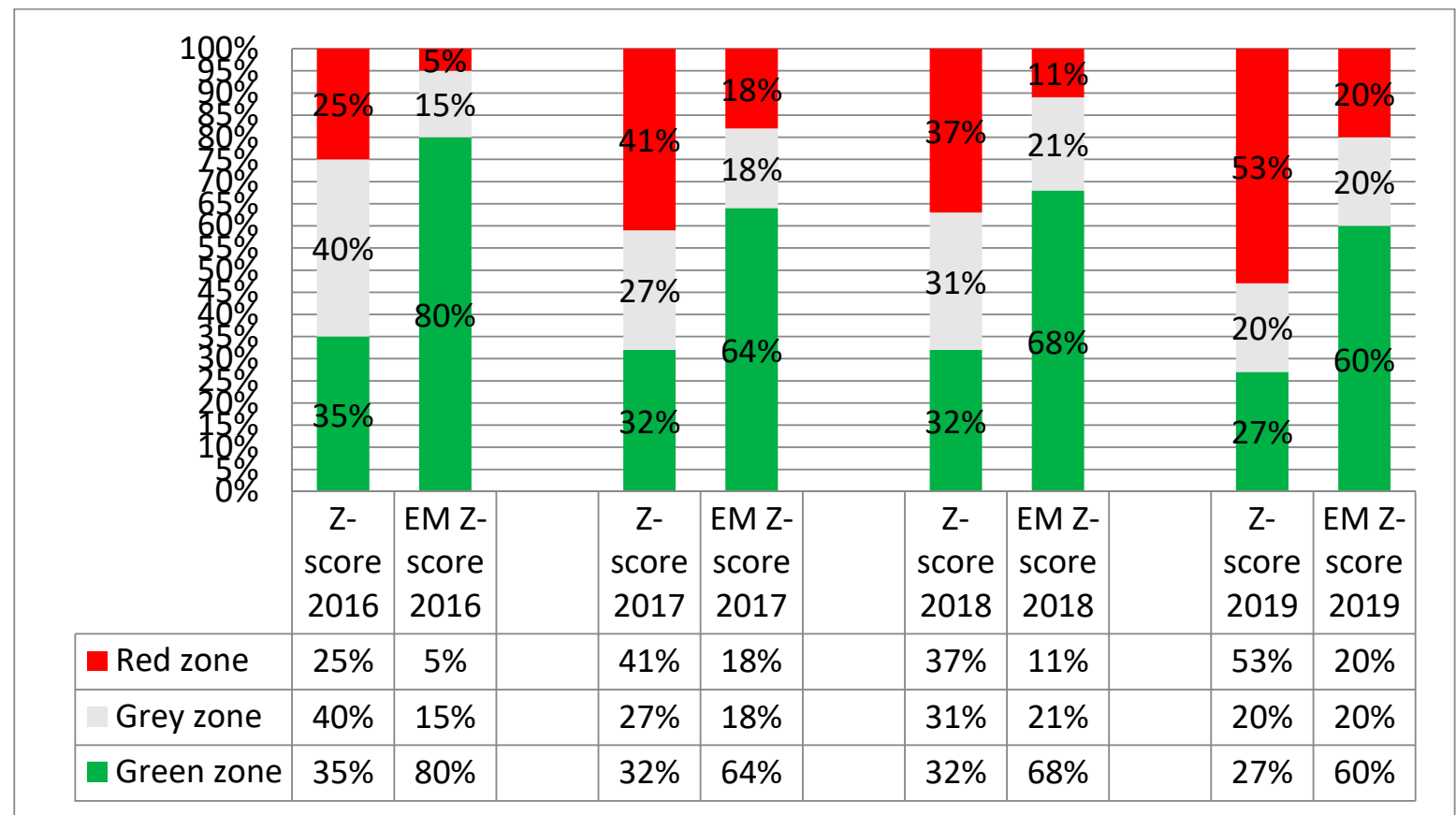

Figure 3. Classification of companies in which there are no indications that fraud has been committed in the financial statements (determined M (5)—score). Source: Author's analysis based on [76,77].

Further, the results of the Z-score model adjusted for companies operating in emerging markets show a better financial situation in companies for which, in the period 2016-2019 and using the M-score model with eight variables, there were no indications that fraud had been committed in the financial reports, relative to the initial Z-score model (Figure 4).

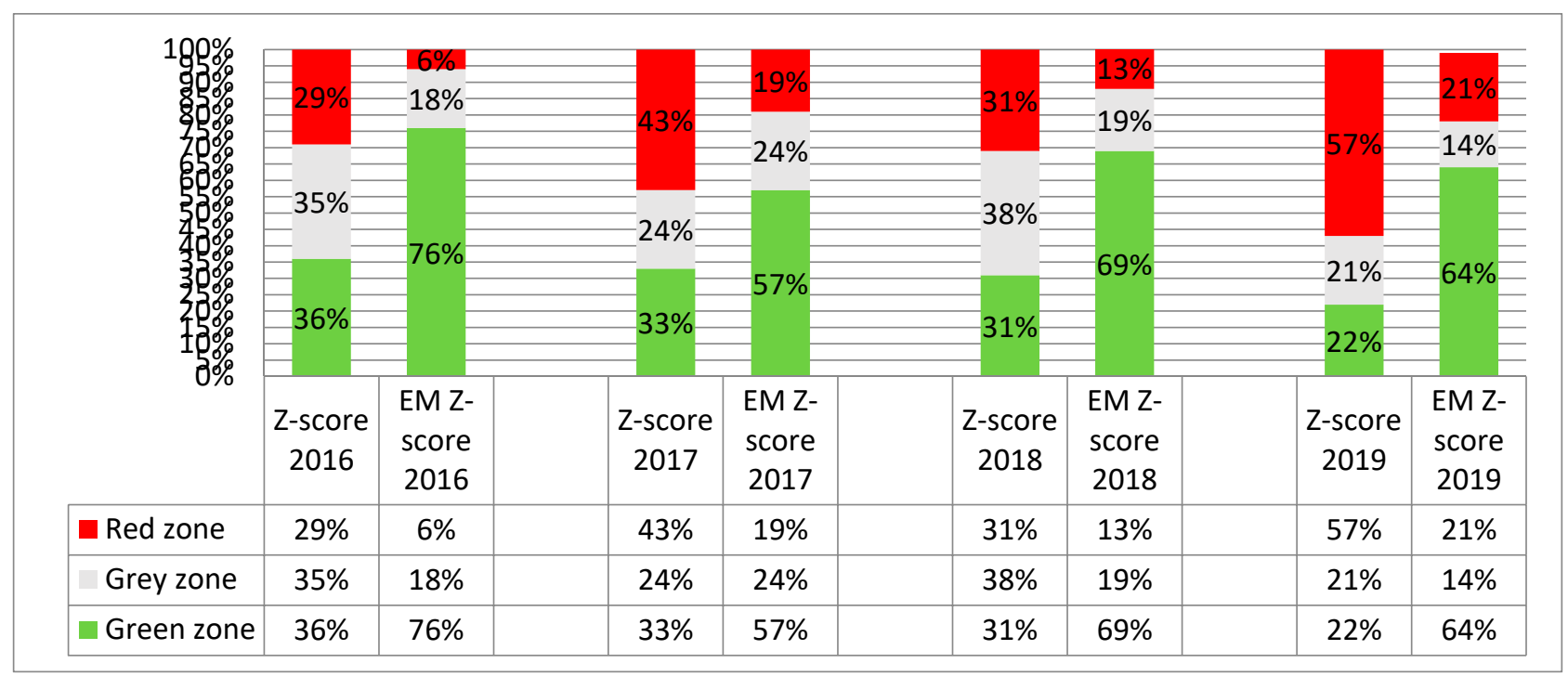

Figure 4. Classification of companies by zones, for which there are no indications that fraud has been committed in the financial statements (determined M (8)—score). Source: Author's analysis based on [76,77]. 


\section{Conclusions}

The importance of predicting bankruptcy years prior to its development is monumental. Such predictions can help many stakeholders to evaluate the condition of a company that they are involved in or want to be connected with. In addition, the possibility of predicting corporate distress and bankruptcy is a powerful tool that can secure the survival of companies that are on the verge of failure. Therefore, Altman's Z-score models present instruments of high value for all interested parties.

The goal of applying Z-statistics is not to predict when companies will enter bankruptcy, but to identify the probability of bankruptcy. In this context, it is highlighted that these statistics provide a signal to a company that it is necessary to take action to improve the company's earnings or current financial position. Further, this is also useful for other interest groups, such as lenders (to reduce credit risk) and potential investors (indicators about the company's insolvency position).

It is necessary to consider the limitations of applying this test. The Altman Z-score is not widely used by start-ups that have generated low or no earnings, and that do not address the issue of cash flow directly. In addition, to ensure valid results are obtained with this test, it is important to note that accounting practices and financial statements should not be fraudulent. Because the internal knowledge of managers is essential to the evaluation and potential distortion of accounting data, it is logical to state that external users of financial statements will find it particularly difficult to distinguish fraudulent from valid financial information when making different business decisions (investment, loans).

The contribution of this paper is that it shows the differences in the results of Z-score models and how to use these results to calculate and interpret bankruptcy probability. It is easy to see that fewer companies from the sample found themselves in the red zone when comparing the model for companies operating in emerging markets to the initial model, and that this is where the true difference between models can be observed. Some companies would have been misclassified in the red zone area when using the initial model, but the model for companies operating in emerging markets (which best suits the companies from the sample) improved their classification position. Furthermore, the research subjects of this paper were companies whose shares are listed on the Belgrade Stock Exchange under sector A-Agriculture, forestry, and fisheries. In addition, by examining and analyzing the results of the applied methods, this paper indicates that sector A-Agriculture, forestry, and fisheries, of the Belgrade Stock Exchange is stable, and that most of the companies included in this sector can expect a bright future.

Our results are useful to different stakeholders, among which investors and creditors stand out, who need to find out in time whether there is a possibility that the company may go bankrupt, in order to avoid large losses. By warning about the upcoming financial troubles of companies, it is possible to minimize losses. Managers may be warned early on to take appropriate action to improve the financial position of the company whose resources they manage. The results of the research obtained by applying the Altman Z-score model can be useful for auditors who evaluate the financial performance of the company during the audit process based on financial indicators, and the results obtained by applying the Beneish M-score model can indicate the possibility of fraud in financial reports.

Improvement in non-financial reporting in the Republic of Serbia should be expected with the implementation of the new Accounting Law from 2020, which prescribes the preparation of non-financial reports for large legal entities that are public interest entities, in addition to companies that exceed the average number of 500 employees during the business year. The mentioned law prescribes the information that must be presented in the non-financial report, which is an integral part of the annual business report. Thus, it contains information necessary to understanding the development, business results, and position of the legal entity, in addition to the results of its activities related to the minimums for environmental protection, social and personnel issues, respect for human and minority rights, anti-corruption, and issues related to bribery, including: (a) a brief description of the business model of the legal entity; (b) a description of the legal entity's 
policies related to these issues, including the basic analysis procedures carried out; (c) the results of these measures; (d) the basic risks associated with the business issues of the legal entity, including, where relevant and necessary, its business relationships, and products or services that may give negative results in these areas, in addition to the manner in which the legal entity manages these risks; (e) non-financial key performance indicators relevant to a particular business.

Further research may consider qualitative information, such as management characteristics and changes in management style. The future directions of research could include the development of a set of indicators as predictors of non-financial and financial characteristics, for the early signaling of the success or failure of companies.

Author Contributions: B.S., S.K., B.M., M.M. and J.T. carried out all the stages of the paper, including conceptualization, methodology, analysis, writing-original draft preparation, and review and editing. V.B.A. was involved in conceptualization and writing-original draft preparation and review and editing. All authors have read and agreed to the published version of the manuscript.

Funding: This research received no external funding.

Acknowledgments: The authors would like to thank the editors and the anonymous reviewers of this journal.

Conflicts of Interest: The authors declare no conflict of interest.

\section{References}

1. Vržina, S.; Dimitrijević, M. Determinants of profitability of the agricultural sector of Vojvodina: The role of corporate income tax. Eur. J. Appl. Econ. 2020, 17, 1-19. [CrossRef]

2. Kuzman, B.; Đurić, K.; Mitrović, L.; Prodanović, R. Agricultural budget and agriculture development in Republic of Serbia. Econ. Agric. 2017, 64, 515-531. [CrossRef]

3. Bogicević, J.; Domanović, V.; Obradović, V. Agriculture, forestry and fishing sector profitability in the Republic of Serbia. Fresenius Environ. Bull. 2020, 29, 9730-9740.

4. Statistical Office of the Republic of Serbia. National Accounts Statistics Gross Domestic Product. 2020. Available online: www.stat.gov.rs (accessed on 21 April 2021).

5. Đurić, D.; Ristić, J.; Đurić, D.; Vujanić, I. Export of agricultural and food products in the function of economic growth of Republic of Serbia. Econ. Agric. 2017, 64, 887-900. [CrossRef]

6. Vukoje, V.; Miljatović, A.; Zoranović, T. Evaluation of the financial position of companies from the agricultural sector. Agroeconomica 2017, 46, 119-131.

7. Zelenović, V.; Vojinović, Ž.; Cvijanović, D. Serbian agriculture loans with the aim of improving the current situation. Econ. Agric. 2018, 65, 323-336. [CrossRef]

8. Pejanović, R.; Njegovan, Z. Actual problems of agricultural and rural development of Serbia. Industry 2009, 37, 87-99.

9. Vukadinović, P.; Vujović, S.; Vojnović, B. Analysis of the financial position of enterprises in privatization in the agricultural sector in Serbia. Econ. Agric. 2018, 65, 955-970. [CrossRef]

10. Stanojević, J.; Krstić, B.; Đekić, S. An analysis of the labour productivity of the agricultural sector in the Republic of Serbia. Econ. Themes 2015, 53, 467-482. [CrossRef]

11. Ristić, L.; Todorović, V.; Jakšić, M. Limitations and opportunities for funding agriculture and rural development in the Republic of Serbia. Econ. Agric. 2018, 65, 1123-1138. [CrossRef]

12. Jolović, J.; Njegovan, Z.; Čavlin, M. Financing of the agriculture in Serbia: State and Prospects. Econ. Agric. 2016, 61, 127-137. [CrossRef]

13. Tang, H.; Liu, Y.; Huang, G. Current Status and Development Strategy for Community-Supported Agriculture (CSA) in China. Sustainability 2019, 11, 3008. [CrossRef]

14. Mariyono, J. Improvement of economic and sustainability performance of agribusiness management using ecological technologies in Indonesia. Int. J. Product. Perform. Manag. 2019, 69, 989-1008. [CrossRef]

15. John, L.; Narayanamurthy, G. Converging sustainability definitions: Industry independent dimensions. World J. Sci. Technol. Sustain. Dev. 2015, 12, 206-232. [CrossRef]

16. Voinov, A.; Farley, J. Reconciling sustainability, systems theory and discounting. Ecol. Econ. 2007, 63, 104-113. [CrossRef]

17. Scrimgeour, F. Agriculture: Continued Strengths. In Public Policy and Governance Frontiers in New Zealand; Berman, E., Karacaoglu, G., Eds.; Emerald Publishing Limited: Bingley, UK, 2020; Volume 32, pp. 91-112. [CrossRef]

18. Dillard, J.; Dujon, V.; King, M. Understanding the Social Dimension of Sustainability; Routledge: London, UK, 2009.

19. Zapico, F.; Hernandez, J.; Borromeo, T.; McNally, K.; Dzon, J.; Fernando, E. Traditional agro-ecosystems in Southern Philippines Vulnerabilities, threats and interventions. Int. J. Disaster Resil. Built Environ. 2019, 10, 289-300. [CrossRef] 
20. Sankat, C.K.; Pun, K.F.; Motilal, C.B. Adopting a National Innovation Approach for Agro-Sustainability: A Case Study. Asian J. Qual. 2006, 7, 98-106. [CrossRef]

21. Rambe, P.; Khaola, P. The impact of innovation on agribusiness competitiveness: The mediating role of technology transfer and productivity. Innovation on agribusiness. Eur. J. Innov. Manag. 2021. [CrossRef]

22. Abeles, T.P. Is sustainability a viable concept for planning? Foresight 1999, 1, 265-273. [CrossRef]

23. Sajan, M.P.; Shalij, P.R. A multicase study approach in Indian manufacturing SMEs to investigate the effect of Lean manufacturing practices on sustainability performance. Int. J. Lean Six Sigma 2020. [CrossRef]

24. Goyal, P.; Rahman, Z.; Kazmi, A.A. Identification and prioritization of corporate sustainability practices using analytical hierarchy process. J. Model. Manag. 2015, 10, 23-49. [CrossRef]

25. Matzembacher, D.E.; Meira, F.B. Sustainability as business strategy in community supported agriculture: Social, environmental and economic benefits for producers and consumers. Br. Food J. 2019, 121, 616-632. [CrossRef]

26. Ratri, M.C.; Harymawan, I.; Kamarudin, K.A. Busyness, Tenure, Meeting Frequency of the CEOs, and Corporate Social Responsibility Disclosure. Sustainability 2021, 13, 5567. [CrossRef]

27. Ordóñez-Castaño, I.A.; Herrera-Rodríguez, E.E.; Franco Ricaurte, A.M.; Perdomo Mejía, L.E. Voluntary Disclosure of GRI and CSR Environmental Criteria in Colombian Companies. Sustainability 2021, 13, 5405. [CrossRef]

28. Das, M.; Rangarajan, K. Impact of policy initiatives and collaborative synergy on sustainability and business growth of Indian SMEs. Indian Growth Dev. Rev. 2020. [CrossRef]

29. Erokhin, V.; Endovitsky, D.; Bobryshev, A.; Kulagina, N.; Ivolga, A. Management Accounting Change as a Sustainable Economic Development Strategy during Pre-Recession and Recession Periods: Evidence from Russia. Sustainability 2019, 11, 3139. [CrossRef]

30. Jovanović, D.; Janjić, V. Motives for, benefits from and accounting support to the ISO 14001 standard implementation. Econ. Horiz. 2018, 20. [CrossRef]

31. Rinaldi, C.; Cavicchi, A.; Spigarelli, F.; Lacchè, L.; Rubens, A. Universities and smart specialisation strategy. Int. J. Sustain. High. Educ. 2018, 19, 67-84. [CrossRef]

32. Dabija, D.-C.; Postelnicu, C.; Dinu, V.; Mihăilă, A. Stakeholders' perception of sustainability orientation within a major Romanian University. Int. J. Sustain. High. Educ. 2017, 18, 533-553. [CrossRef]

33. Ascani, I.; Ciccola, R.; Chiucchi, M.S. A Structured Literature Review about the Role of Management Accountants in Sustainability Accounting and Reporting. Sustainability 2021, 13, 2357. [CrossRef]

34. Novo-Corti, I.; Badea, L.; Tirca, D.M.; Aceleanu, M.I. A pilot study on education for sustainable development in the Romanian economic higher education. Int. J. Sustain. High. Educ. 2018, 19, 817-838. [CrossRef]

35. Gagnidze, I. The role of international educational and science programs for sustainable development (systemic approach). Kybernetes 2018, 47, 409-424. [CrossRef]

36. Melles, G. Integrating Sustainable Development into the Postgraduate Curriculum in the UK: A Mixed Method Study. In Teaching and Learning Strategies for Sustainable Development (Innovations in Higher Education Teaching and Learning); Sengupta, E., Blessinger, P., Yamin, T.S., Eds.; Emerald Publishing Limited: Bingley, UK, 2020; Volume 19, pp. 123-140. [CrossRef]

37. Jerold, W.B. Bankruptcy costs: Some evidence. Papers and Proceedings of the Thirty-Fifth Annual Meeting of the American Finance Association. J. Financ. 1977, 32, 337-347.

38. Dimiras, A.I.; Zanakis, S.H.; Zopounidis, C.A. Survey of business failures with an emphasis on prediction methods and industrial applications. Eur. J. Oper. Res. 1996, 90, 487-513. [CrossRef]

39. Edward, A.I. Evolution of the bankruptcy process. In Corporate Financial Distress: A Complete Guide to Predicting. Avoiding, and Dealing with Bankruptcy; Wiley: New York, NY, USA, 1983.

40. Schumpeter, J.A. Can capitalism survive? In Capitalism, Socialism and Democracy; Taylor \& Francis e-Library: London, UK, 2003; pp. 255-260.

41. Ganyam, A.I.; Ivungu, J.A. Effect of accounting in formation system on financial performance of firms: A review of literature. IOSR J. Bus. Manag. 2019, 21, 39-49. [CrossRef]

42. Carp, M.; Istrate, C. Audit Quality under Influences of Audit Firm and Auditee Characteristics: Evidence from the Romanian Regulated Market. Sustainability 2021, 13, 6924. [CrossRef]

43. Mitrić, M.; Stanković, A.; Lakićević, A. Forensic Accounting: The Missing Link in Education and Practice. Management 2012, 65, 41-50. [CrossRef]

44. Dimitrijević, D.; Obradović, V.; Milutinović, S. Indicators of fraud in financial reporting in the Republic of Serbia. TEME 2018, 42 , 1319-1338. [CrossRef]

45. Dun \& Bradstreet Inc. Dun \& Bradstreet's Failure Record; Dun \& Bradstreet: Short Hills, NJ, USA, 1980.

46. Edward, A.I.; Edith, H.; Wei, W. Corporate financial distress. In Corporate Financial Distress, Restructuring, and Bankruptcy: Analyze Leveraged Finance, Distressed Debt, and Bankruptcy; John Wiley \& Sons, Inc.: Hoboken, NJ, USA, 2019.

47. Hutahayan, B. The mediating role of human capital and management accounting information system in the relationship between innovation strategy and internal process performance and the impact on corporate financial performance. Benchmarking Int. J. 2020, 27, 1289-1318. [CrossRef]

48. Jovanović, D.; Todorović, M.; Grbić, M. Financial Indicators as Predictors of Illiquidity. Rom. J. Econ. Forecast. 2017, $20,128-149$.

49. Altman, E.I.; LaFleur, J.K. Managing a return to financial health. J. Bus. Strategy 1981, 2, 31-38. [CrossRef] 
50. Calandro, J. Considering the utility of Altman's Z-score as a strategic assessment and performance management tool. Strategy Leadersh. 2007, 5, 37-43. [CrossRef]

51. Seppa, R. Implication of inside-debt: Signalling for bankruptcy probabilities within small firms. Balt. J. Manag. 2014, 9, 168-188. [CrossRef]

52. Purves, N.; Niblock, S.J.; Sloan, K. On the relationship between financial and non-financial factors: A case study analysis of financial failure predictors of agribusiness firms in Australia. Agric. Financ. Rev. 2015, 75, 282-300. [CrossRef]

53. Salehi, M.; Mousavi, S.M.; Bolandraftar, P.M. Predicting corporate financial distress using data mining techniques: An application in Tehran stock exchange. Int. J. Law Manag. 2016, 58, 216-230. [CrossRef]

54. Marinšek, D. Why Does a Firm Go Bankrupt? In Challenges on the Path Toward Sustainability in Europe; Žabkar, V., Redek, T., Eds.; Emerald Publishing Limited: Bingley, UK, 2020; pp. 101-126. [CrossRef]

55. Hu, D.; Zheng, H. Does ownership structure affect the degree of corporate financial distress in China? J. Account. Emerg. Econ. 2015, 5, 35-50. [CrossRef]

56. Vasilev, D.; Cvetković, D.; Grgur, A. Detection on fraudulent actions in the financial statements with particular emphasison hotel companies. Hotel Tour. Manag. 2019, 7, 115-125. [CrossRef]

57. William, B.H. Financial Ratios as Predictors of Failure. Empirical Research in Accounting: Selected Studies. J. Account. Res. 1966, 4, 71-111.

58. Edward, A.I. Financial ratios, discriminant analysis and the prediction of corporate bankruptcy. J. Financ. 1968, 23, 589-609.

59. Edward, A.I. Corporate credit scoring-Insolvency risk models. In Corporate Financial Distress and Bankruptcy: A Complete Guide to Predicting $\mathcal{E}$ Avoiding Distress and Profiting from Bankruptcy; Wiley: New York, NY, USA, 1993.

60. Edward, A.I.; Kishore, V. The default experience of U.S. Bonds, Working Paper. In Damodaran on Valuation: Security Analysis for Investment and Corporate Finance; Damodaran, A., Ed.; Wiley: New York, NY, USA, 1999.

61. Plumley, D.; Serbera, J.-P.; Wilson, R. Too big to fail? Accounting for predictions of financial distress in English professional football clubs. J. Appl. Account. Res. 2020, ahead-of-print. [CrossRef]

62. Nagel, R.; Aviles, C. The impact of corporate bankruptcy on strategic management: Using a textual analysis approach to analyze executives' opinions. J. Indian Bus. Res. 2021. [CrossRef]

63. Cenciarelli, V.G.; Greco, G.; Allegrini, M. Does intellectual capital help predict bankruptcy? J. Intellect. Cap. 2018, 19, 321-337. [CrossRef]

64. Meeampol, S.; Lerskullawat, P.; Ausa, T.; Srinammuang, P.; Rodpetch, V.; Noonoi, R. Applying Emerging Market Z-Score Model to Predict Bankruptcy: A Case Study of Listed Companies in the Stock Exchange of Thailand (Set). In Proceedings of the Human Capital without Borders: Knowledge and Learning for Quality of Life, the Management, Knowledge and Learning International Conference, Portorož, Slovenia, 25-27 June 2014.

65. Linna, T. Insolvency proceedings from a sustainability perspective. Int. Insolv. Rev. 2019, 28, 210-232. [CrossRef]

66. Cooper, E.; Uzun, H. Corporate social responsibility and bankruptcy. Stud. Econ. Financ. 2019, 36, 130-153. [CrossRef]

67. Salehi, M.; Pour, M.D. Bankruptcy prediction of listed companies on the Tehran Stock Exchange. Int. J. Law Manag. 2016, 58, 545-561. [CrossRef]

68. Succurro, M.; Arcuri, G.; Costanzo, G.D. A combined approach based on robust PCA to improve bankruptcy forecasting. Rev. Account. Financ. 2019, 18, 296-320. [CrossRef]

69. Altman, E.I.; Sabato, G.; Wilson, N. The Value of Non-Financial Information in Small and Medium-Sized Enterprise Risk Management. J. Credit. Risk 2010, 6, 1-33. [CrossRef]

70. Gupta, J.; Barzotto, M.; Khorasgani, A. Does size matter in predicting SMEs failure? Int. J. Financ. Econ. 2018, 23, 571-605. [CrossRef]

71. Muminović, S.; Pavlović, V.; Cvijanović, J.M. Predictive ability of various bankruptcy prediction Z-score models for Serbianpublicly listed companies. Industry 2011, 39, 1-12.

72. Panrad, T. Using Alman's EM-Score Model to Analyze Bakruptcy: A Case Study of Agribusiness Sector in the Stock Excange of Thailand. Econ. Manag. Innov. 2017, 1, 94-96. [CrossRef]

73. Rajin, D.; Milenković, D.; Radojević, T. Bankruptcy prediction models in the Serbian agricultural sector. Econ. Agric. 2016, 1, 89-104. [CrossRef]

74. Stanišić, N.; Mizdraković, V.; Knežević, G. Corporate Bankruptcy Prediction in the Republic of Serbia. Industy 2013, 41, 145-159. [CrossRef]

75. Beneish, D.M. The Detection of Earnings Manipulation. Financ. Anal. J. 1999, 55, 24-36. [CrossRef]

76. Belgrade Stock Exchange Sectors Class. A Sector-Agriculture, Forestry and Fishery. 2021. Available online: https://www.belex. rs/trzista_i_hartije/sektori/\%EF\%BB\%BFA (accessed on 18 March 2021).

77. Register of Financial Statements. The Serbian Business Registers Agency. Register of Financial Statements. 2021. Available online: https:/ / www.apr.gov.rs/\%d0\%bf\%d0\%be\%d1\%87\%d0\%b5\%d1\%82\%d0\%bd\%d0\%b0.3.html (accessed on 18 March 2021).

78. Repousis, S. Using Beneish model to detect corporate financial statement fraud in Greece. J. Financ. Crime 2016, 23, 1063-1073. [CrossRef]

79. Đukić, T.; Pavlović, M. The Quality of Financial Reporting in the Republic of Serbia. Econ. Themes 2014, 52, 101-116. [CrossRef] 
80. Todorović, M. Non-financial reporting in the context of theories and practices of the European Union. In Economic and Social Aspects of Serbia's Accession to the European Union; Jakšić, M., Aleksić, V.S., Mimović, P., Eds.; Faculty of Economics University of Kragujevac: Kragujevac, Serbia, 2015; pp. 403-412.

81. Singhvi, S.; Desai, H. An Empirical Analysis of the Quality of Corporate Financial Disclosure. Account. Rev. 1971, 46, 129-138.

82. Alfaraih, M.M.; Alanezi, F.S. What Explains Variation in Segment Reporting? Evidence from Kuwait. Int. Bus. Econ. Res. J. 2011, 10, 31-46. [CrossRef]

83. Jan, C. An effective financial statements fraud detection model for the sustainable development of financial markets: Evidence from Taiwan. Sustainability 2018, 10, 513. [CrossRef] 